\title{
A Study on Attracting Local And International Investments and Improving an Integrated Logistics System Allows Local Products to Reach Global Markets
}

\author{
Abdulaziz Khalid Mohammed Al-Makhmari, Hind Huwaishal Al Yaqoopi, and Zouhaier Slimi
}

\section{ABSTRACT}

This paper studies how local non-oil Omani products could reach global markets by attracting local and international investors and improving the integrated logistics system in Oman. Therefore, the scope of this research is investment agencies in Oman, which are the Ministry of Commerce, Industry, and Investment Promotion and the Public Authority for Investment Promotion and Export Development. This study targets the leading logistics companies in Oman, such as Asyad Group. The study used an online survey and direct interview targeting specialists and experts in investment agencies and logistics companies. The results of the research showed that challenges are facing attracting local and international investors in local industries. Those challenges are the lengthy, complicated and costly procedures to obtain permits and licenses for investors, weak promotion of investment opportunities and local products at the international level, weakness of the local market, cumbersome regulations of the government, and so on. All these challenges constitute an obstacle to attracting investments. Findings also vindicate that weaknesses in logistical performance represented by the complex export and import procedures, complications in customs clearance operations, and the weak performance of land, sea, and air transport, which constitutes a barrier to exporting local products to global markets. The primary limitations that the researchers faced in conducting this research. First, there were many complications in collecting information through interviews. Some companies refused to conduct interviews due to preventive measures for the spread of the Coronavirus, which may affect the results.

Keywords: Artificial intelligence, Integrated logistics, Investment, Promotion.

\author{
Submitted : July 12, 2021 \\ Published : August 03, 2021
}

ISSN: 2507-1076

DOI: $10.24018 /$ ejbmr.2021.6.4.982

Abdulaziz Khalid Mohammed AlMakhmari

B.A student the Logistics and Transport Management department, International Maritime College Oman, Sohar, Oman.

(e-mail: 03362-15@imco.edu.om) Hind Huwaishal Al Yaqoopi

Assistant Lecturer- Logistics and transport management, International Maritime College Oman, Sohar, Oman.

(e-mail: hind@imco.edu.om)

Zouhaier Slimi*

Lecturer Foundation Department, International Maritime College Oman, Sohar, Oman.

(e-mail: zouhaier@imco.edu.om)

*Corresponding Author

\section{INTRODUCTION}

First, the manufacturing sector is considered one of the main drivers in developing the national economy. It constitutes an added value in economic diversification and reduces its dependence on oil revenues. The Sultanate of Oman is significantly dependent on oil and gas revenues, comprising between $68 \%$ and $85 \%$ of government revenues. So, Oman vision 2040 focusing on the industrial strategy. It aims to increase opportunities for local manufacturing, enhance the purchasing power of the national product, and enter new markets at the regional and international levels by the development of the non-oil industrial sector to reduce dependence on oil and diversify the Omani economy [1].

\section{A. Background of the Research}

In the past few years, many companies and factories that manufacture local non-oil products established. Therefore, the Omani products have achieved development and diversification at the local level, as they became a solid competitor to foreign products in the local markets [1].
According to the national campaign to promote Omani products under the slogan (Made in Oman), more than 235 manufacturing companies registered [2]. These manufacturers produce various local products such as pens, the manufactured paper, aluminium products, dairy products, plastic products, food products, and many other manufacturers. All these products are available in local markets. However, when looking for local products in global markets, there is a weakness or non-availability of some of those products in those markets, which means exporting some Omani products to the international and Gulf markets, but very little. Therefore, most of the products still face difficulties and challenges in accessing global markets.

An excellent example of this is Mazoon products. An Omani company produces various products such as milk, yoghurt, juices, ice cream, and other products widely present in the local markets and competes with Almarai Company. However, these products are not found in global markets, such as Europe, America, and the Gulf. [3]. Therefore, it became necessary to support Omani products and help them to reach international markets. Moreover, this research study aims to attract local and international investments and 
improve the integrated logistics system to help and support Omani products reach global markets and become known everywhere.

\section{B. Statement of the Problem}

This research study will attract local and international investments and improve an integrated logistics system to support domestic products to reach global markets. So, according to the background of this study, there is a weak of available local products in international markets because of the many challenges facing manufacturing companies, which constitute an obstacle to exporting their products to global markets. According to the analytical report of the development of manufacturing industries of Oman preparing for the future, this report shows the general challenges facing manufacturing companies in Oman, as shown in the table below [4].

TABLE I: PROBLEMS ENCOUNTERED BY PRODUCERS AND MANUFACTURERS [4]

\begin{tabular}{cc}
\multicolumn{2}{c}{ MANUFACTURERS [4] } \\
\hline Problems encountered by manufacturing companies \\
\hline High cost of production & Insufficient storage capacity \\
Unfair competition & Insufficient production capacity \\
Shortage of skilled operatives & Telecommunication and IT \\
Transport problems & Inadequate supply of water \\
Shortage of raw materials & Lack of equipment \\
İnsufficient demand & Shortage of management skills \\
İnadequate supply of electricity & Illegal imports \\
Financial problems & Poor quality of raw materials. \\
\hline
\end{tabular}

Thus, these barriers impacted exporting Omani non-oil products to the outside and low competition between it and foreign products in local and international markets. In addition, the Sultanate of Oman depended heavily on oil and gas revenues. As illustrated in Fig. 1, in 2017, the fuel sector ranked first in Omani exports, while exports of industrial, agricultural, and other non-oil products witnessed stagnation and weak exports to global markets [5].

\section{TRADE}

\section{Oman's Exports by product (\%)}
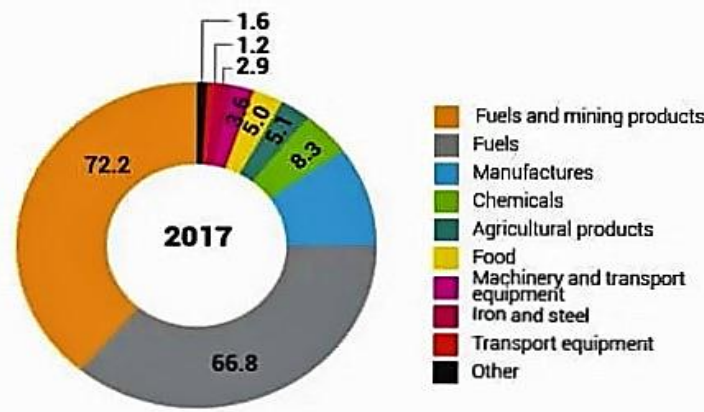

Fig. 1. The percentage of exporting Omani products in 2017. Source: [5].

Accordingly, it becomes necessary to attract foreign and local capital to invest in local products to overcome all those challenges. An investment allocates money to purchase an asset or an item to generate additional income [6]. On the other hand, this study focuses on improving the logistics system and providing facilities for transporting local products with high efficiency and without obstacles. Logistics is the flow of products, services, and information from production to consumption point [7].

\section{Research Questions}

- Main question

1. How can Omani products reach the global market and become known everywhere?

- Sub-questions

1. What are the factors affecting on attract local and international investors to invest in local manufacturing?

2. What are the challenges of attracting investments that influence attracting local and international investors?

3. What are the challenges that affect the logistics performance in Oman and that constitute an obstacle to exporting local products?

4. What is the value of attracting investors and improve the integrated logistics system for Oman?

5. What are the best proposal recommendations to attract investors to invest in local products and improve the integrated logistics system in Oman?

\section{Research Objectives}

1. To analyse the obstacles that possibly influence on attract investors to Oman.

2. To explore the factors that are affecting on attract local and international investors.

3. To determine the challenges that impact logistics system productivity.

4. To identify strategies, incentives, and pillars of attracting investments.

5. To propose recommendations to two ways:

- To improve the logistics system in Oman to be able to transport local products outside.

- To attract local and international investments.

\section{E. Research Justification}

Several incentives motivated the researcher to research this topical issue due to the weak and unavailability of local non-oil products in global markets. So, attracting local and foreign investments to invest in local non-oil industries will play an influential role in overcoming local manufacturers' and producers' challenges and supporting Omani exports to global markets. In addition to increasing the contribution of the manufacturing sector to the GDP to reduce the Sultanate's dependence on oil revenues, reduce the unemployment rate in Oman and increase job opportunities.

Furthermore, according to the article on the logistics sector in Oman, the logistics sector still has not reached the required level globally due to some challenges facing the logistics and transportation industries [8]. Therefore, this study is considered a source for improving the logistic sector to facilitate and encourage import and export through the land port, seaport, and airports and increase the performance and effectiveness of the logistic system. As a result, Oman will be the most preferred logistic station in the world.

\section{F. Research Significant}

Conducting this type of study is very significant important and reflects many benefits. Firstly, attracting local and international investment in local industries can help create local and international competition and form trade relations with various countries. The investment will also add many 
benefits to Oman, such as introducing, recovering the manufacturing sector, and sharing experience and knowledge with local producers [9].

Moreover, the logistical sector' improvement will help promote commercial traffic through operating seaports, land and air routes to export Omani products. Also, this will help attract many logistic companies, shipping lines, and other stockholders [10]. Also, it is contributing to economic diversification, providing job opportunities, and achieving self-sufficiency of local products

\section{G. Scope of Research}

The scope of this research study limits is the investment agencies and logistics companies because it highlights the performance and efficiency of the logistics system and attracts investments. Therefore, this research study will target the Ministry of Commerce, Industry, and Investment Promotion in Sohar, responsible for attracting investments. In addition to the Public Authority for Investment Promotion and Export Development in Muscat. Also, the scope of this study will be covering some logistic companies in Sohar port and free economic zone to identify the logistical performance in Oman and the challenges it faces.

\section{H. Limitation of the Research}

There were several limitations that the researcher faced in conducting this research. First, there were many complications in collecting information through interviews. Some companies refused to conduct interviews due to preventive measures for the spread of the Coronavirus, which may affect the results. Second, the researcher faced difficulty collecting secondary data from the literature review because no previous studies were related to this research study.

\section{LITERATURE REVIEW}

This research study focuses on a very topical issue attracting local and international capital to invest in local products and improve the integrated logistics sector to support Omani non-oil exports and enhance their presence in competing globally. Because most Omani products still face challenges in reaching international markets. Due to the importance of this study, there are many articles, research, and views on how to attract investments and develop the logistics sector to become an integrated sector that contributes to efficiently transferring local products to global markets. This review aims to use statistics, published reports, recent studies, and other sources to compile the data and information required by this research paper. Also, to know the authors' opinions on the research study to support it with valuable information.

\section{A. Statistics of Non-oil Omani exports}

According to the report published by NCSI about the manufacturing industries in Oman, the value of non-oil exports in 2018 amounted to (4.4) billion OMR, an increase of $19.7 \%$ compared to 2017. Among the most important countries to which Omani products were exported in 2018 (Billion OMR), UAE (1.0), Qatar (0.495), Saudi Arabia (0.458), India (0.296), China (0.281), other countries (1.8) Billion OMR. Moreover, the most important exports of nonoil products in 2018 (billion OMR), (0.3) manufacturing of transportation equipment, (0.5) manufacturing of food products, (1.0) primary industries of minerals, (1.0) the manufacture of chemical materials and products, and other products amounted to (1.2) billion OMR [11].

\section{B. Investments Benefits}

Most countries attract foreign and local investors through a website review because there are potential benefits from this activity [12]. Investors help transfer technology and technical and administrative expertise to the host country, assisting local products and services in entering new markets, training its national workforce, upgrading their skills, and creating job opportunities. Moreover, investors contribute to increasing individual income, developing research and innovation, and diversifying the country's income sources through investment in infrastructure, industrial and productive projects [13].

\section{Pillars of Encouraging Investments in Oman}

According to the study about Foreign Investment Promotion Analysis in Sultanate of Oman, in 2016, Oman ranked 4 in the ease of doing business in the GCC countries (Table III). The reasons behind this are that the Sultanate of Oman has an integrated group of pillars attracting foreign and local investment. The three most important factors are geographical location, political stability, and industrial and free zones [14].

\section{1) Strategic locations}

Oman has a strategic location overlooking many international markets. Also, its geographical location on East-West trade routes helps it access markets in the Middle East, India, South- East Asia, Africa, and Europe. On the other hand, Oman borders Saudi Arabia, the United Arab Emirates to the West, and Yemen in the South. So, this will help the investors to reach quickly for that market.

\section{2) Political stability}

Oman has a stable political system and peaceful coexistence among all members of society. Moreover, Omani laws on justice and equality in rights and duties between citizens and residents. Also, it has a strong relationship with all world countries.

\section{3) Industrial and free zones}

Oman has four free economic zones. Three zones are in the three main ports: Sohar, Salalah, and Duqm. In contrast, the fourth economic zone is in Al Mazunah. It is located only $4 \mathrm{~km}$ from the Yemeni border, which helps investors reach the Yemeni markets. Besides, it has eight industrials' zones: Al Rusayl, Sohar, Raysut, Sur, Nizwa, Al Buraimi, Samail, and Ibri. Services and facilities for investors support all zones. So, it provides attractive investment opportunities [15].

TABLE II: EASE OF DOING BUSINESS INDEX GCC

\begin{tabular}{ccc}
\hline Ranking & GCC country & Index value \\
\hline 1 & United Arab Emirates & 75.10 \\
2 & Bahrain & 66.81 \\
3 & Qatar & 65.97 \\
4 & Oman & 65.40 \\
5 & Saudi Arabia & 63.17 \\
6 & Kuwait & 60.17 \\
\hline
\end{tabular}

Source: World Bank doing business 2016.GCC. 


\section{Factors Affecting Attract Local and International Investment}

According to many articles, most countries have taken actions and many measures to provide a suitable investment climate by promoting the investment system and improving the business environment to attract local and foreign investors [16]. The survey was conducted on many studies related to the policies and factors affecting attracting foreign and local investments (Fig. 2). Studies indicate that many countries have succeeded in attracting locally manufactured products, such as China, Thailand, and Ireland [17].

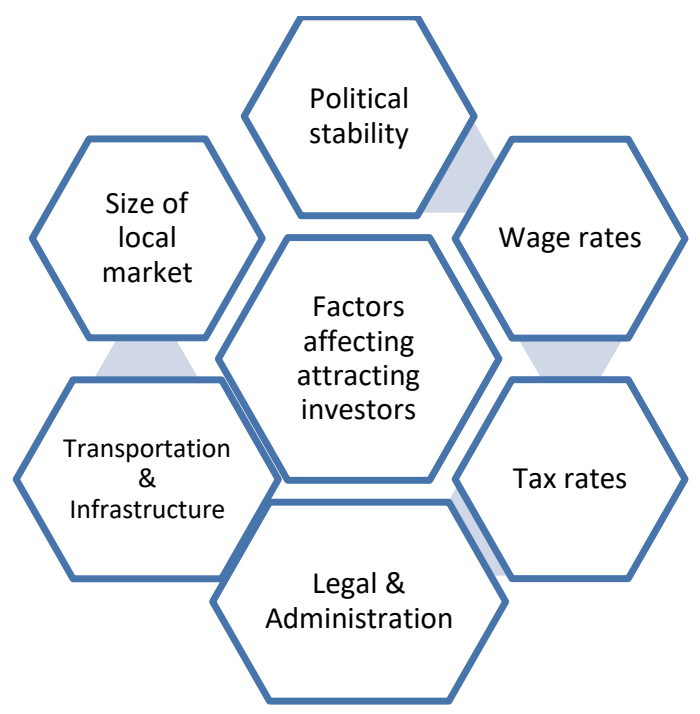

Fig. 2. Factors affecting investors' attraction [18].

\section{1) Political factor}

A study has proven that political stability is the primary determinant of investment flows. The investor will not risk transferring his capital and technical expertise to a country with wars and political instability.

\section{2) Transport and infrastructure}

One of the critical factors in attracting local and international investors is transportation costs and infrastructure levels. If there are high transportation costs to export goods to global markets, then this is a challenge. So, infrastructure development is the primary key to attracting foreign investment by establishing advanced and integrated transport networks to transfer products, provide modern communication systems and an information network, and installing industrial and free zones [16].

\section{3) Economic factors}

Economic factors play a crucial role in attracting investments, focusing on stability, diversification, and economic growth [13]. The economic factors are: -

\section{E. Market Size}

Market size always depends on the size of the demand. The larger the market, the more attractive it is for investment. Because the investor always focuses on sufficient demand to cover costs and make profits. Many studies have proven that the investor is attracted to the country witnessing expansion in its markets. Also, there is a strong relationship between GDP growth as a measure of market growth. The growth of the gross domestic product leads to an increase in the per capita income, which makes him aspire to new goods. Hence, there must be investments to cover this growing demand [13].

\section{1) Inflation rate}

High inflation rates lead to economic instability and affect pricing policy, production costs, and market profitability. Therefore, the country must maintain inflation rates, meaning that it does not exceed $3 \%$ to attract more investments.

\section{2) Exchange rates}

The fluctuations in the exchange rate negatively affect the flow of investments because it reduces profits and affects production costs. Several applied studies confirmed the existence of an inverse relationship between fluctuations in exchange rates and investment flows. Therefore, the state must maintain exchange rates to be able to attract investments.

\section{3) Legal and administration factors}

Legal factors play an influential role in attracting investments. It states the provision of protection and guarantees for the investors, such as the freedom to transfer profits and capital abroad and the existence of transparent and clear laws that protect the investor from all risks. Also, the organisational factors facilitate procedures and unify the investor's authority to obtain licenses, permits, and other documents as soon as possible. [19].

\section{4) Wage rates}

Investors seek to find low-cost labour to increase profit. Therefore, a country with trained, qualified, and cheap labour is more stimulating and attractive to invest in [18].

\section{5) Labour skills}

Firms constantly invest in low-wage countries but have highly skilled and productive workers. For example, India has attracted investment in call centres because it has a high percentage of English-speaking English with low labour wages. That makes it an attractive country for outsourcing and thus attracts foreign companies [20].

\section{6) Tax rates}

Companies seek to invest in countries with low corporate tax rates. An excellent example of this, Ireland has succeeded in attracting investments from Google and Microsoft because Ireland does not impose taxes on investing companies [20].

\section{F. Strategies to Attract Investors}

\section{1) Import substitution industrialisation (ISI)}

Some countries apply a strategy for developing the local products, which is import substitution industrialisation (ISI) [14]. It means the government must block some imports of foreign products or reduce them from local markets. The strategy will stimulate local manufacturers and producers to compete in manufacturing these products to respond to the local market [14]. Nevertheless, this requires capital to develop products and expand factories to increase productivity. Therefore, this will help attract local and international investors and encourage them to invest in products because they are sure there is no competitor in the market and will achieve more profits. After being selfenough locally, local products will export it to international markets. 


\section{2) Remove trade barriers}

In addition, Adam Smith said that one of the strategies for developing the manufacturing sector and attract investors is to remove trade barriers, which is one of market liberalisation. Because these barriers will lead to many obstacles to exporting and importing products and achieving high efficiency in the local markets, but before market liberalisation, the government must improve the infrastructure and facilities. Otherwise, it will reflect negatively on the sector [14].

\section{G. Promotion Investment and Trade}

According to the research about promoting investment and trade, marketing is among the most critical factors in attracting foreign and domestic investments. It shows clients and investors what the country offers regarding opportunities, incentives, and advantages for investors. Moreover, investors need critical information before investing, such as suitable business partners, location, market size, costs, available skills, taxes, incentives and guarantees, laws and regulations, and other information. However, this information must be valuable and attractive to investors. On the other hand, investors need to know some information about exporting, such as tariffs, product regulations, environmental standards, potential importers in global markets. Besides, the marketing of local products will open doors for foreign companies to invest in them. So, responsible for Promotion are investment promotion agencies. Investment promotion agencies provide information and advice to investors about local industries [21]. Also, it helps foreign companies find local partners for joint ventures and strategic alliances. They can be marketed abroad through international exhibitions and conferences. The marketing aims to make the country known between foreign investors and importers. Moreover, promotional efforts aim to convey local products and industries of some industries and companies as attractive business partners. Also, it will support local industries in expanding their businesses and help their products to enter new markets by attracting investment [22].

\section{H. The Role of Integrated Logistics}

An integrated logistics system is defined as the process of integration, coordination, and participation between all parties involved in the flow of goods, services, and information in the supply chain system from the production point to the consumption point [23]. Some studies have proven that the growth in international trade and openness to global markets has constantly improved the country's logistical capabilities. As no company in the world can carry out commercial operations, import and export processes, transport, and manufacture of materials and products without an integrated and competitive logistics sector at the global level. The improvement of the logistics integrated can lead to an increase in the volume of trade, distribution, and production activities, reduce costs, increase the flow of local exports to global markets, and so on [24]. On the contrary, Poor logistics services, such as lack of coordination between countries regarding border procedures, inefficiency in customs clearance, poor infrastructure, costly shipping, delay in tracking and tracing shipments, delays in handling and clearing cargo, lack of storage and facilities, lack of modes of transportation, inadequate of skills and experiences, lack of equipment and services, will lead to significant hindrance the flow of goods to global markets. Therefore, integrated transportation and logistics systems motivate local producers to safely transport their products to consumers in a costeffective and time-efficient manner [25].

\section{Challenges Faced by the Logistics and Transportation Industry}

Below are some of Oman's logistics system challenges that the sector must overcome to remain competitive and grow [26].

\section{1) Technological advancements}

The logistics system is facing several challenges due to disruptions caused by technological advances, and logistics companies must adopt these advancements as an enabler of competition and growth in the future. So, it became necessary for companies to keep pace with these developments by establishing intelligent and integrated logistics facilities capable of dealing with all types of goods, storing and moving goods with high efficiency, and coordinating all stakeholders.

\section{2) Employment laws}

Oman has imposed laws to increase the number of Omani nationals working in the logistics sector. The challenge here is to impart training to the workers to make them employable and gain the required skills. Therefore, logistics must be a part of all educational curricula for the individual to have a background in the logistics sector. Also, government institutes, agencies, and bodies should implement training programs to develop workforce skills.

\section{3) Transportation costs}

One of the biggest challenges the logistics system faces is the high transportation costs due to increasing fuel costs in Oman, which negatively affects the logistics budget, which leads to higher freight rates that customers must pay. To solve this problem, logistics companies should start using a responsive transportation system that allows for faster identification of issues to provide economical solutions. Also, they can use other technologies such as autonomous tracking and AI. This technology uses to reduce transportation costs and maintain the performance and efficiency of transportation network systems.

\section{4) Workforce management}

With the development and fast growth of the transportation and logistics industry, logistics companies need a more rapid and highly efficient workforce. It causes a challenge for companies to find skilled workers to keep pace with this development. To overcome this issue, logistics companies should use modern technology, such as robots and drone technology, to accelerate operations and increase efficiency, productivity, and performance in the supply chain.

\section{J. Supply Chain Integrated}

The Logistics Performance Index (LPI) that was put by the World Bank reveals that there are many integrations in the supply chain that are producing, and logistics companies must follow to increase the flow of their products to global 
markets and reduce logistics costs [24].

\section{K. Work Practices Integration}

The integration of workforce practices helps increase supply chain performance, move products with high efficiency, handle large volumes of supply chain flows, and reduce congestion. This integration occurs when employees have sufficient experience and knowledge and manage the work as a group through cooperation and harmony. Besides, employee training and gaining experience will also meet international requirements for supply chain management such as productivity, quality, and reliability, reducing labour disputes and other disruptions.

\section{1) Technology integration}

Technology contributes to elevating the logistics sector to global competitiveness by using the latest technology in all parties in the supply chain. Also, it uses information technology between supply chain parties to coordinate, sharing information and knowledge electronically about inventory levels, customers, production, and other data.

\section{2) Regulatory integration}

It is the coordination and integration of the regulations between countries, such as safety regulations, including the safety of goods from theft, loss, delay, damage, environmental regulations to reduce emissions and noise, cross-border regulations such as documents, specifications of goods, customs, and others. Due to supply chain management includes operations and modes across many countries, organisational integration becomes critically important to avoid jurisdictions and international problems.

\section{Research Gaps}

The objective of this research study was to determine and overcome the research gaps. Based on the purposes and hypotheses of the study, which represent in:

- Find out the obstacles that possibly influence on attract investors to Oman.

- To explore the factors that are affecting on attract local and international investors.

- To determine the challenges that impact logistics system productivity.

- To identify strategies, incentives, and pillars of attracting investments.

The numbers of studies and research are limited, and there is insufficient and inaccurate information on this research study. Moreover, Studies did not focus on attracting local and foreign investments to invest in local products, which means most studies were discussing attracting investment in general, such as attracting investment in the education, health, and tourism sector. Also, according to the objectives of this study, the researcher wants to know the challenges facing attracting investors in Oman to overcome and create an attractive environment for investors, but no studies were discussing these challenges. On the other hand, several research studies have focused on the factors that attract investment without having strategies and solutions that help attract foreign and domestic investments.

\section{RESEARCH METHODOLOGY AND DATA COLLECTION}

A. Research Framework

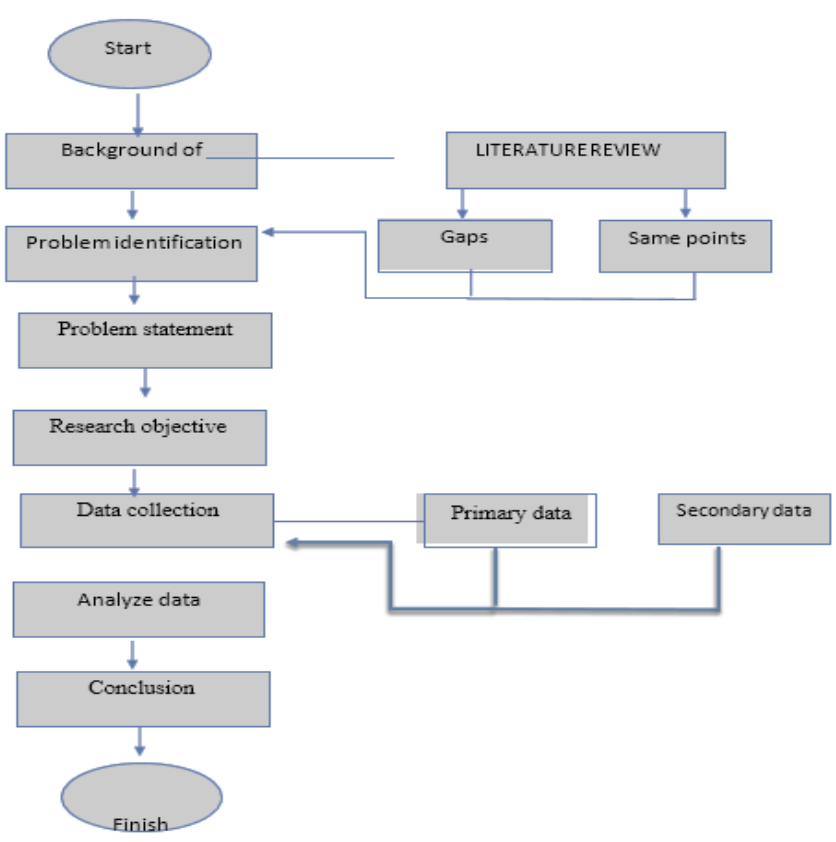

Fig. 3. Research Framework/Design.

This figure illustrates the stages of the research methodology to reach the best results. The first stage is about an introduction. In this stage, the researcher writes a background of attracting local and international investors and improving the logistics system to support local products reach global markets. Moreover, the researcher is defining the problem statement and the importance and benefits of this research study. Furthermore, the researcher reviewed the articles, studies, and research related to this research study in the second stage. To compare and identify research gaps where the researcher has identified the essential strategies and factors that affect attracting investments and the most critical challenges facing the logistics system in Oman. After reviewing the literature, the researcher extracted the gaps from the study. The third stage of this study is the research methodology. In this stage, the researcher focusing on gathering data by using several tools and methods to reach the right results. Therefore, the research methodology relied on the mixed method, which combines quantitative data (questionnaire) and qualitative data (interviews). The fourth stage is data analysis. After obtaining the data in the third stage, the researcher will analyse it in two ways: descriptive analysis and thematic analysis, to make the data valuable and easy to read. In the final stage, it is the stage of making decisions and making suggestions to overcome this issue.

\section{B. Data Collection}

\section{1) Mixed method}

The mixed-method is a method that combines qualitative and quantitative methods in one study. This method provides power to the research study using the data more thoroughly and comprehensively [27]. Moreover, mixed methods help understand the discrepancies between quantitative and qualitative results. The study results of this method also depend on getting in-depth and accurate information through the respondents' concepts, ideas, and experiences. Also, 
quantitative data can help validate qualitative data Therefore, this study requires qualitative and quantitative data to achieve the objectives of this research study.

\section{2) Qualitative methods}

In this research study, the researcher will use qualitative methods to collect the data, which expresses by words [28]. The qualitative method aims to get knowledge and information based on the human experience. So, it will use in the interview with specialists and experts. Because interviews always help the researcher to obtain data in-depth, valuable with high accuracy. By asking the respondents open questions and taking their notes. This method will provide a large amount of data, and this is what this study needs to analyse the data the best way [29], given that this research study requires current data. So, the interviews will help the researcher to obtain Fresh information in an easy and fast way.

\section{3) Quantitative methods}

Also, the researcher will use quantitative methods to collect the data. The quantitative method deals with data in numbers, graphs, and statistics [29]. Therefore, data were collected through polls, questionnaires, and surveys. In addition, the information in the quantitative method is measurable, and multiple opinions can be analysed and compared to obtain the best results [28]. Moreover, this study needs to take the views and perspectives of large numbers of respondents to know their satisfaction with the performance of the logistics sector and the investment sector in Oman.

\section{4) Pilot test}

After completing prepare the survey questions, the researcher used the pilot test. The beta test allows the researcher to ensure that the online survey runs smoothly and without any problems by rehearsing with several persons. This pilot test will significantly improve the results of the research study.

\section{Sampling Technique and Potential Respondents}

Sampling techniques select a sample of targeted respondents from the population to take conclusions, opinions, and information related to the research study. Because it is tough to conduct a research study with all populations. Therefore, researchers use two sampling methods: probability sampling and non-probability sampling [30].

\section{1) Probability sampling}

This research study will be based on probability (random) sampling through an online survey because all people will have equal opportunities to be part of the sample. The survey will target people working in logistics companies and investment agencies. To identify their satisfaction with the logistics performance in Oman and what is a lack in the sector to be an integrated logistics sector capable of transporting products to global markets. In addition to their opinions on attracting local and international investors [30].

\section{2) Non-probability sampling}

On the other hand, the researcher will use non-probability (non-random) sampling for the interviews because this method identifies potential person interviews. Not everyone can participate [30]. The researcher will conduct interviews with officials from the Ministry of Commerce, Industry, Investment Promotion, and the Public Authority for investment promotion and export development to find out challenges attracting investments. In addition, to identify investment attraction strategies and the ministry's plans in this regard. Also, an interview will be held with Asyad Group to determine the performance of the logistics system in Oman and the challenges facing it.

\section{Data Analysis}

The researcher will use two types of data analysis tools which are thematic analysis and descriptive analysis.

\section{1) Thematic analysis}

Thematic analysis will use to analyse the data that the researcher will get from the interviews. Thematic analysis is the best way to analyse qualitative data because it divides and classifies large amounts of information in an easy-tounderstand manner, which helps produce a clear and organised final study. Also, it delivers reliable, accurate, and valuable results [31].

\section{2) Descriptive analysis}

Descriptive analysis will use to analyse the data that the researcher will obtain from the questionnaire. It helps analyse the numerical and statistical data collected in a quantitative research project into graphs to be accessible and readable [32]. The main goal of data analysis is to get valuable results that support decision-making in attracting local and international investors and improving the logistics system in Oman.

\section{FINDINGS AND DISCUSSIONS}

\section{A. Survey Findings}

This section discusses the results of the survey that the researcher conducted in April 2021. The questionnaire aims to obtain opinions and views of workers in logistic companies and investment agencies. Furthermore, the questionnaire focused on several themes the availability of qualified and trained workers in the logistics services sector, the efficiency of the land, sea, air transport, marketing and promotion of investment opportunities and Omani products, import and export procedures, and process of customs clearance. In addition, warehouses and storage facilities capacity in Ports and airports, and procedures for investors to obtain permits. Moreover, the survey targeted five companies: Hutchison ports Sohar (Oman international container terminal), C. Steinweg Oman LLC, Asyad group, Sohar production project, and Khimji Ramdas shipping. Also, it targeted the public Authority for investment promotion and export development.

As per the above chart, this chart shows the age group of participants in the survey. The total number of respondents was 104 , a majority of them are within the age group of 31 40 years with $32 \%$, and $29 \%$ of the respondents are in the age group 26-30 years. While $28 \%$ of participants are in the age group $18-25$ and $11 \%$ were $41-50$. 


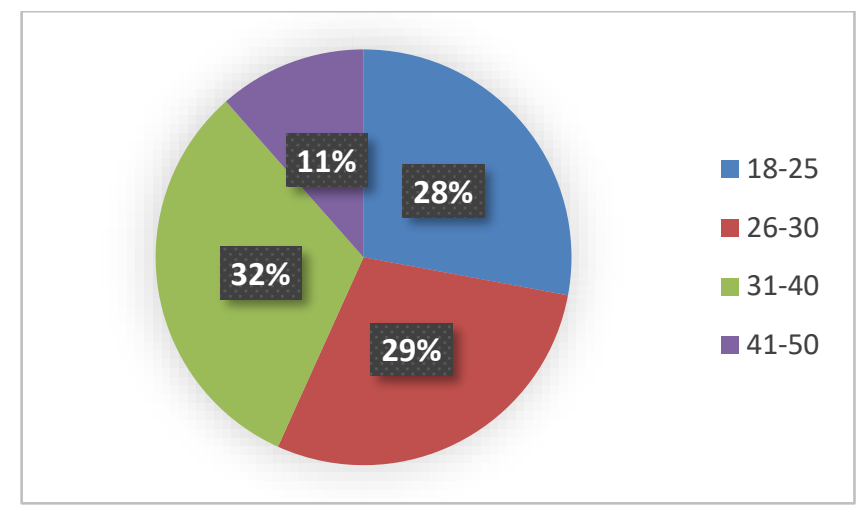

Fig. 4. Participant Age.

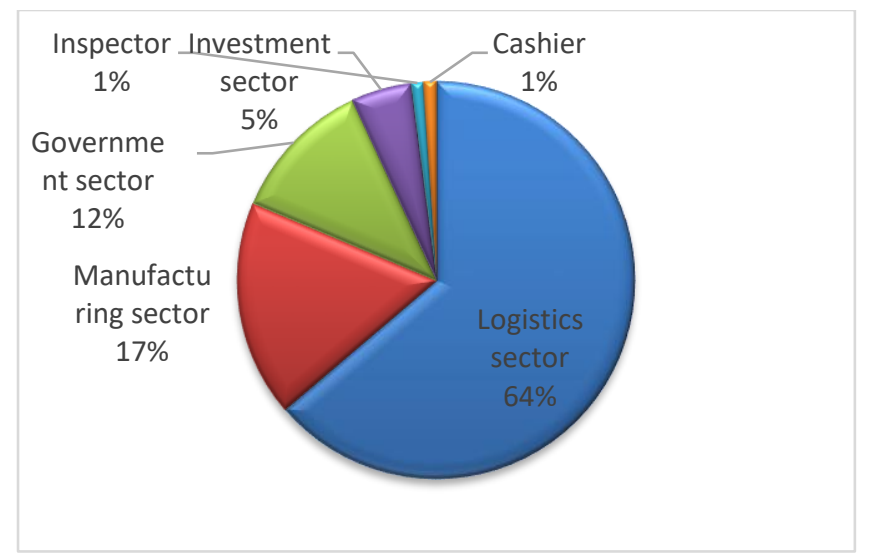

Fig. 5. Participant's work sector.

This chart shows the sectors in which the participants work. Most than half of the participants work in the logistics sector, with $64 \%$ and $17 \%$ in the manufacturing industries. While $12 \%$ in the government sector. At the same time, $5 \%$ of participants are working in the investment sector, and the other participants were working in different jobs.

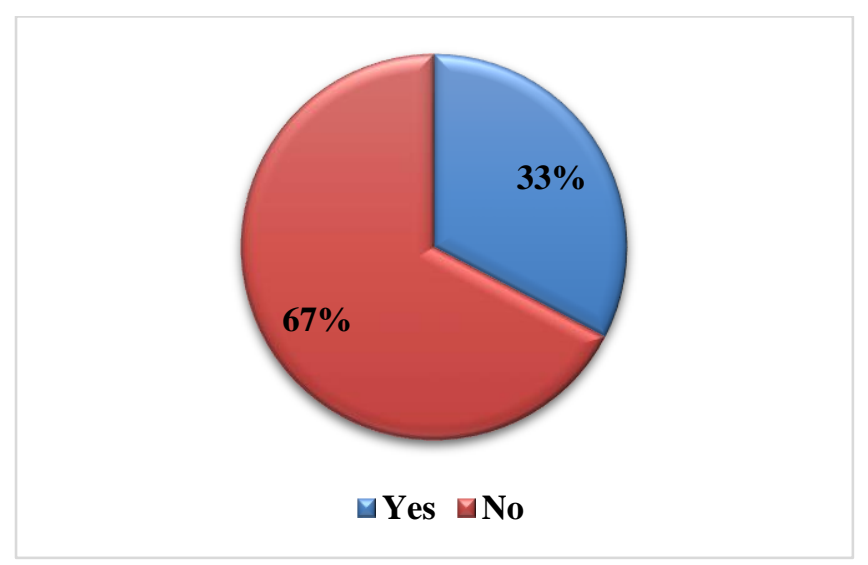

Fig. 6. Qualified workforces in the logistics sector.

This graph measures the availability of qualified and trained national workers in the logistics sectors. $67 \%$ of the participants think that there is enough skilled national workforce in the logistics sector. In contrast, $33 \%$ of the participants see there is a shortage.

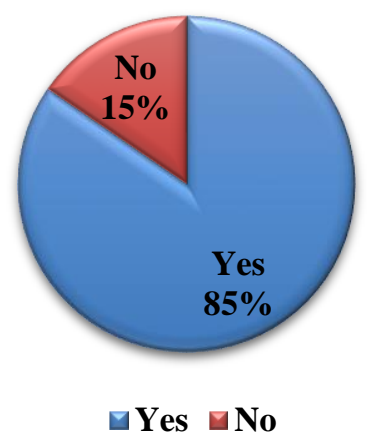

Fig. 7. Investments and local products promotion.

The above chart shows the performance of promotional campaigns for investments and local products at the international level. $85 \%$ of participants think there is a weakness in marketing investment opportunities and local products. In contrast, $15 \%$ of participants see that marketing campaigns for local products and investment promotion are strong and work well.

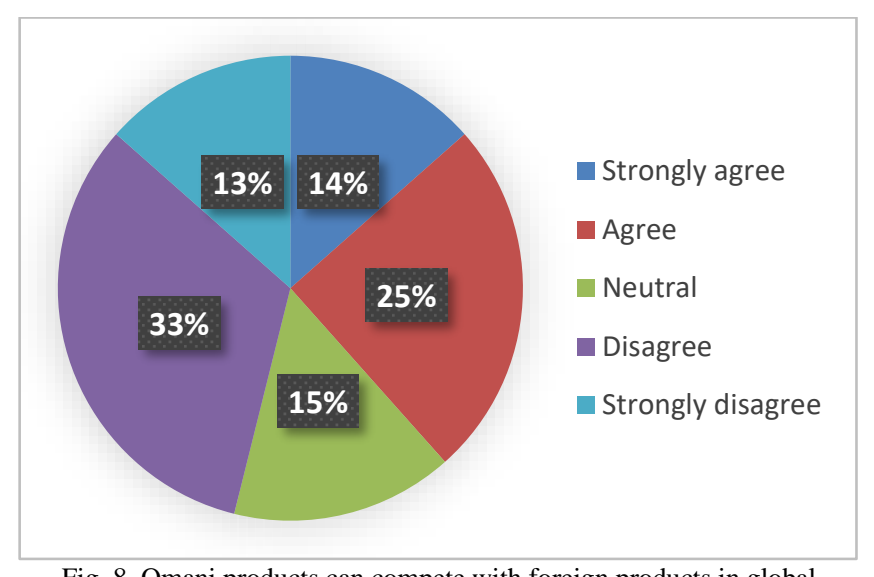

Fig. 8. Omani products can compete with foreign products in global markets.

This chart shows the strength and of the competition of Omani products in the global market. However, $33 \%$ of the respondents disagreed, and they think that Omani products cannot compete in international markets. While $25 \%$ of participants agree, $15 \%$ were neutral, and $14 \%$ of respondents strongly agreed. In addition, $13 \%$ strongly disagreed.

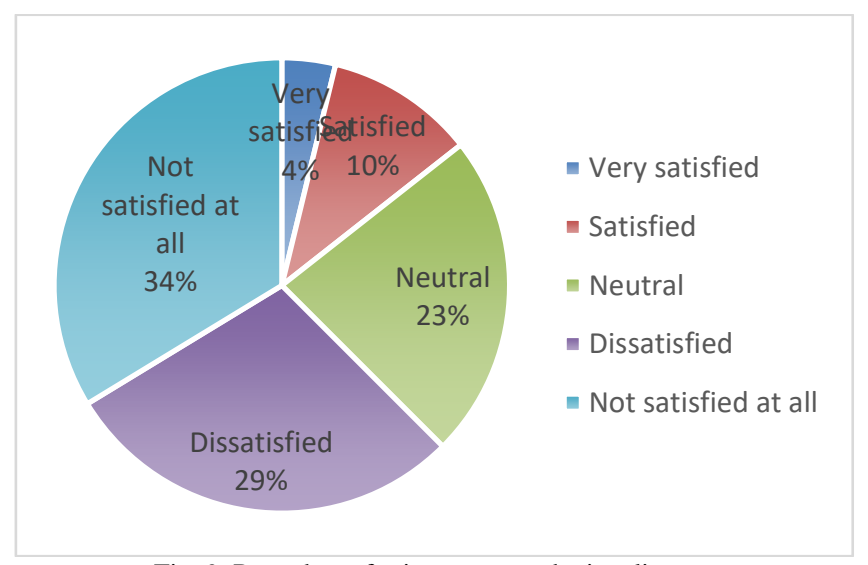

Fig. 9. Procedures for investors to obtain a license. 
This graph shows the participants' level of satisfaction around the investors getting permits and licenses. $63 \%$ of the participants are not satisfied or dissatisfied and think there are complications in obtaining licenses. While $23 \%$ were neutral, $10 \%$ were satisfied, and $4 \%$ were only participants very satisfied.

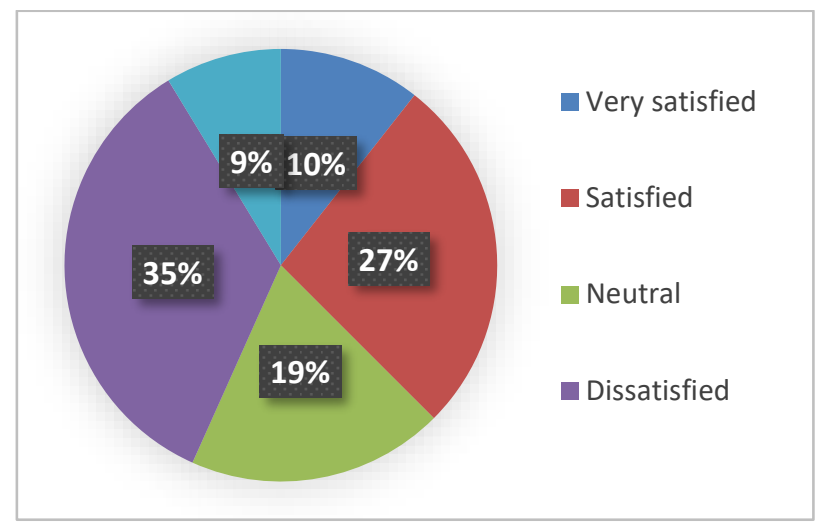

Fig. 10. The performance of the transport sector.

This chart shows the efficiency, performance, and quality of land, air, and sea transport in the Sultanate of Oman. Most of the respondents (44\%) were dissatisfied, and some were dissatisfied. In contrast, $37 \%$ of the respondents were very satisfied or satisfied. In addition, $19 \%$ were neutral.

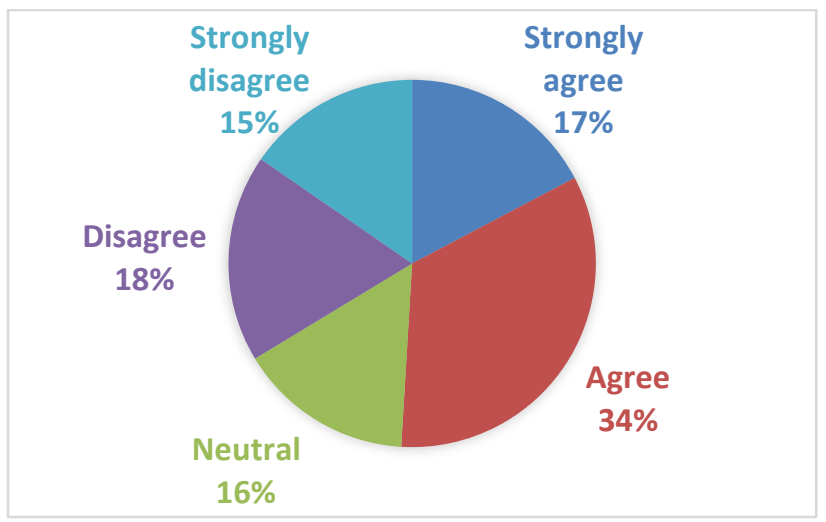

Fig. 11. The customs clearance procedures.

This chart shows the performance of customs clearance at the land, air, and seaports. $51 \%$ of the respondents agree or strongly agree that customs clearance procedures in the transport sector are complicated, expensive, and complex. In contrast, $33 \%$ of the participants disagree, and some of them strongly disagree. In addition, $16 \%$ were neutral.

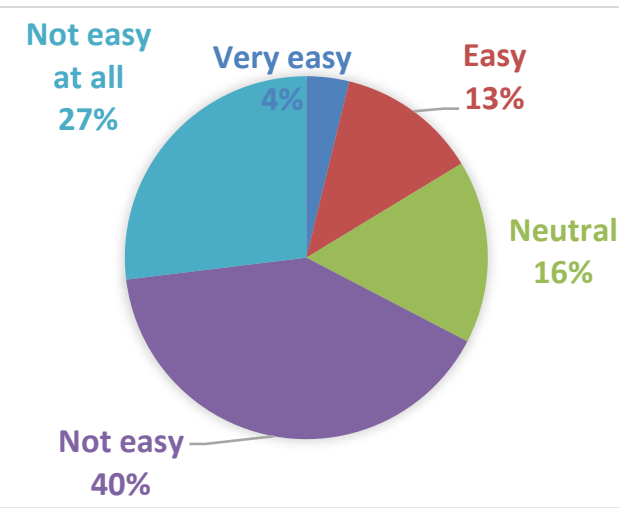

Fig. 12. The procedures of import and export.
This chart shows how easy the procedures for export and import to and from Oman are. $67 \%$ of the participants see that the procedures are not easy, while $16 \%$ were neutral. In contrast, $17 \%$ of respondents believe that the import and export procedures are easy or very easy.

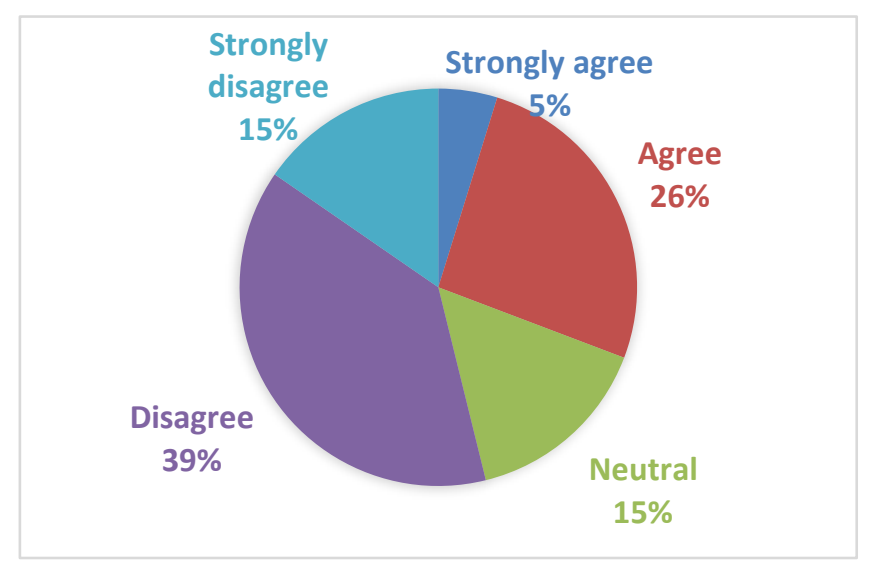

Fig. 13. The capacity of warehouse and storage facilities.

This chart shows the statement that "there is a shortage of the capacity of warehouse and storage facilities in airports and seaports." Do you agree? Most participants (54\%) disagree or strongly disagree with that statement and think there are sufficiently available warehouses and storage facilities. In contrast, $31 \%$ of participants agree or strongly agree. In comparison, $15 \%$ of the respondents were neutral. In your opinion, what strategies can attract local and international investors to invest in Omani products to help it reach global markets?

According to the above question, 35 of the participants gave their opinions. Most of the respondents believed that facilitating procedures for investors obtaining licenses and permits in a short time and without any complications would be an attractive factor in encouraging investors to invest. In contrast, some participants believe that the government should impose high taxes on imported goods and fill the local markets with Omani products to promote investment in local products. In contrast, the rest of the participants believe that promoting Omani products, providing incentives and concessions, and reducing services fees will help investors invest in local products.

In your opinion, how can Oman's logistics sector be an integrated sector and able to transport local products from Oman to the outside?

According to the above question, 33 of the participants gave their opinions. Most participants believe that using technology and developing workers' skills in the logistics sector by participating in courses, workshops, and training to gain experience will help to improve the logistics sector. In contrast, the opinion of other participants is attracting investments in infrastructure and outsourcing, developing laws and regulations, facilitating customs clearance procedures, and increase modes of transportations.

\section{B. Interview's Findings}

In this section, the researcher discusses the findings of the interviews conducted in April 2021. The researcher used the interviews to get accurate and actual information. These interviews targeted three organisations: Asyad group, the 
public authority for investment promotion and export development, and the ministry of commerce, industry, and investment promotion.

TABLE III: INTERVIEWS DESCRIPTION

\begin{tabular}{|c|c|c|}
\hline & Position & Question \\
\hline 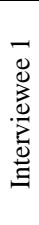 & $\begin{array}{l}\text { Responsible for } \\
\text { approving licences \& } \\
\text { permits for investors at } \\
\text { the ministry of } \\
\text { commerce, industry } \\
\text { and investment } \\
\text { promotion. }\end{array}$ & $\begin{array}{l}\text { What are the barriers against attracting } \\
\text { local and foreign investors in } \\
\text { manufacturing industries? } \\
\text { What are the reasons for the lengthy } \\
\text { and complicated procedures for } \\
\text { obtaining permits and licenses for } \\
\text { investors? }\end{array}$ \\
\hline 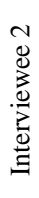 & $\begin{array}{l}\text { Administrative } \\
\text { Coordinator at the } \\
\text { Ministry of } \\
\text { Commerce, Industry } \\
\text { and Investment } \\
\text { promotion. }\end{array}$ & $\begin{array}{l}\text { What are the incentives and privileges } \\
\text { offered by the ministry to local and } \\
\text { international investors? }\end{array}$ \\
\hline 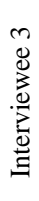 & $\begin{array}{l}\text { The first coordination } \\
\text { specialist at public } \\
\text { authority ror } \\
\text { investment promotion } \\
\text { and } \\
\text { development. }\end{array}$ & $\begin{array}{l}\text { What are the investment initiatives and } \\
\text { opportunities, and how are they } \\
\text { marketed at the international and local } \\
\text { levels? }\end{array}$ \\
\hline 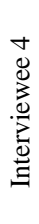 & $\begin{array}{l}\text { Logistics operations } \\
\text { supervisor at Asyad } \\
\text { group }\end{array}$ & $\begin{array}{l}\text { Why is the customs clearance } \\
\text { processes still complicated and lengthy } \\
\text { despite the existence of the Bayan } \\
\text { system? } \\
\text { What are the reasons for the lengthy } \\
\text { and complicated procedures for } \\
\text { exporting products? }\end{array}$ \\
\hline
\end{tabular}

Although the researcher identified the research questions for the interviewers, however, these questions are not fixed. Since qualitative data (interviews) tend to be somewhat exploratory, there can be other questions when discussing.

\section{1) Challenges of attracting investors}

According to an interview with $\mathrm{A}$, responsible for approving licenses and permits for investors electronically at the ministry of commerce, industry, and investment promotion, the researcher asked the most critical challenges that hinder foreign and local investments in local industries? This question aims to identify the challenges and their implications for investors to provide appropriate solutions to remove obstacles to attracting investors. Despite the government's efforts to provide a suitable environment for investors, some obstacles are considered obstacles. Among these obstacles: long and complex procedures to obtain permits and licenses for investors to start a project or participate in local projects, the local market's weakness, lack of investment opportunities, weakness in promotional campaigns, high services costs, and cumbersome government regulations [33].

\section{2) Investment incentives}

According to interviewee $\mathrm{B}$, who works as an administrative coordinator at the Ministry of Commerce, Industry and Investment Promotion, the ministry offers several incentives to encourage investors in other countries and local investors to invest in local industries and support Omani exports in foreign markets. [34]. These incentives are:

\begin{tabular}{|c|c|c|}
\hline \multicolumn{3}{|c|}{ Incentives } \\
\hline & $\begin{array}{l}\text { Taxes/ customs duty } \\
\text { Income tax exemption } \\
\text { for five years for } \\
\text { industrial projects. }\end{array}$ & $\begin{array}{l}\text { General } \\
\text { Foreign investors are allowed to } \\
\text { own the shares in Omani } \\
\text { companies up to } 70 \text { to } 100 \%\end{array}$ \\
\hline 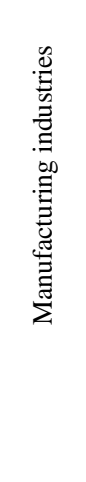 & $\begin{array}{l}\text { Exemption of } \\
\text { production inputs from } \\
\text { taxes and customs } \\
\text { duties such as } \\
\text { equipment, machinery } \\
\text { and raw materials. }\end{array}$ & $\begin{array}{l}\text { Providing financial loans from } \\
\text { Oman development bank. } \\
\text { Foreign investors are allowed to } \\
\text { own commercial land at a } \\
\text { favourable price. } \\
\text { Freedom to transfer capital \& } \\
\text { profit to home country. } \\
\text { Foreign companies are allowed } \\
\text { to open branches in Oman. } \\
\text { Allowing the recruitment of a } \\
\text { non-Omani workforce of up to } \\
10 \% \text { in free \& industrial zones. } \\
\text { The proximity of industrial } \\
\text { areas to logistics services } \\
\text { (ports, airports, roads) }\end{array}$ \\
\hline
\end{tabular}

\section{Analysis of Research Project}

In this section of the research study, the researcher will analyse the findings of interviews and questionnaires to reach ideal and effective results to support decision-making.

\section{1) Survey analysis}

Is there a shortage of qualified and trained national workforce in the logistics sector?

As a result, most participants think there is enough qualified, trained national workforce in the logistics services sector. That means that workers in the logistics sector, whether in seaports, airports, or land ports, have experience handling, shipping, transporting goods, managing ports and warehouses, and all processes in the supply chain. In contrast, if there is a shortage of qualified and experienced workers in the logistics sector, it will lead to some problems, such as processes delay, cargo damages, and losses. In that case, however, it is necessary to develop the skills and capabilities of employees to gain more knowledge and experience and keep pace with the development in the sector and the fourth industrial revolution.

Do you think there is a weakness in promotional campaigns for investment opportunities and local products at the international level?

According to the survey results, most participants believe that there is a weakness in promotional and marketing campaigns for investment opportunities and Omani non-oil products at the international level. Marketing is one of the most critical factors attracting investments because it shows the incentives and concessions that the country provides to investors, opportunities and laws investments, and other valuable information that encourages investors to invest in manufacturing industries.

According to C (2021), the First Coordination Specialist at Public Authority for Investment Promotion and Export Development, many investment opportunities and initiatives are launched by the Ministry of Trade and Industry and investment promotion every year. Whereas, in 2021, the Ministry will launch 50 investment opportunities in the industrial sector. These opportunities will attract investments estimated at more than 200 million Omani riyals to invest in various products, such as the food industry, paper products, rubber products, transport equipment, and other local 
opportunities. However, $\mathrm{t}$ the defect in promoting these investment opportunities to attract local and foreign investors. Among the marketing initiatives, in 2019, the authority launched its online platform (Invest in Oman) to attract investors. This platform provides all the data and information he needs about investment opportunities. But this platform still needs to be developed, marketing at the local and international levels, so that all investors worldwide can view it [35]. On the other hand, the national campaign initiative (Made in Oman) aims to Promote Omani Products and Services to encourage and raise awareness among local consumers to purchase locally produced goods. This promotion plays a significant role in attracting local and international investments because investors always look to companies that can attract customers and increase demand for products [35].

Do you think that Omani products can compete with foreign products in global markets such as American and European Markets?

Many participants believe that Omani products cannot compete with foreign products in those markets. Therefore, according to some articles, the researcher concluded that the dependence of local products on high quality and efficiency would enable them to export to global markets such as Japan, European countries, and the United States. On the other hand, if the quality of the products is poor and weak, the producer cannot export them to Europe and America because these countries follow strict standards for importing products [36]. What is your level of satisfaction with the procedures for obtaining permits and licenses for investors?

According to the survey findings, investors face slow, lengthy, and complicated procedures for obtaining licenses and permits from competent authorities to start investing in the country. Although there is a one-stop-shop system in the Ministry of Trade and Industry and Investment Promotion to facilitate the procedure business of local and international investors, providing online services to clearance all transactions. Therefore, the researcher asked a question in the interview about these complications in the procedures. According to A, responsible for approving licenses and permits electronically for investors at the Ministry of Commerce, Industry and Investment Promotion, this delay might be due to lack of investor data, breakdown of the Ministry's system, work pressure on employees, or procrastination approving permits. Therefore, sometimes there is an easy in getting licenses, and sometimes the matter is very complicated. Interviewee A added that the reason behind the failure of the one-stop shop is the lack of coordination between the concerned authorities [33].

What is the level of your satisfaction with the quality, efficiency, and performance of land, air, and sea transport in the Sultanate of Oman?

It is impossible to export local products without an integrated transport sector capable of transporting products with high efficiency. The respondents were dissatisfied with land, sea, and air transport performance in Oman, whether in cost, services, efficiency, or performance. Therefore, the researcher asked the question in the interview about the reasons for this. According to $\mathrm{D}$, challenges are facing the transport sector that affects its performance. These challenges are the lack of transportation modes, insufficient shipping capacity, environmental pollution, congestion, and high costs such as fuel, freight, insurance, handling, and other charges. So, should overcome these problems to export local products smoothly [37].

Do you agree that customs clearance procedures at the land, sea and airports are complicated, lengthy, and costly?

According to the questionnaire results, most participants think customs clearance procedures in the transport sector are somewhat complicated, negatively affecting the export of local products or importing raw materials. According to a discussion with $\mathrm{D}$, customs clearance processes are still complex and lengthy. Although, there is a bayan system for clearing all procedures and obtaining permits electronically. However, the defect in the inspection processes, because the goods are checked manually and randomly without using modern technologies such as laser technology, leads to delays, damage, loss, or theft of goods [37].

How easy are the procedures for export and import to and from Oman?

As a result of the survey, most participants think exporting the products from and to Oman is not easy. So, if there are no easy exporting and import cargo procedures, the local producers will face challenges in exporting their products. Therefore, they should make it smooth and straightforward to allow local products to move to global markets.

According to a discussion with $\mathrm{D}$, many procedures make the export operations very complicated due to required documents and licenses such as certificate of export, import, or any certifications related to business, and inspection certificates, certificate of Analysis, commercial Invoice, consular Invoice, and weight certificate. Also, insurance certificate, certificate of Origin issued, certificate of Free Sale, customs clearance documents, customs bond, legal Undertaking, customs declarations, and purchase order or Letter of Credit. All these documents are deposited electronically before arriving at the seaport, airport, or land port by the bayan system. Still, it takes a long time and high costs to get them from the competent authorities [37].

There is a shortage of warehouse capacity and storage facilities at seaports and airports. Do you agree with this statement?

Suppose the capacity of warehouses and storage facilities in seaports and airports is not sufficient. In that case, it will lead to many problems, including stopping operations (loading or unloading) and financial losses, which will affect the export of goods. Therefore, according to the survey results, most participants believe that warehouses and storage facilities are sufficiently available in seaports and airports. However, with the attraction of investments in local products, probably international trade will increase. Therefore, it is necessary to increase the capacity of seaports and airports to receive large quantities of products.

\section{Interview Analysis}

\section{Challenges of attracting investments}

\section{1) The multiplicity of agencies responsible for attracting} investments

Agencies responsible for attracting investments in the Sultanate are multiple and have a conflict of jurisdiction. That means that the investor does not deal with only one party to obtain an investment license but with various 
agencies and ministries. That led to increased procedures and a lack of coordination between different parties. That will lead to the investor's escape or puts the investor in confusion and anxiety in investing. In a realistic story with an investor, a foreign investor wanted to invest in a food production company due to the delay in obtaining licenses and permits from the competent authorities, which lasted six months. The investor decided not to invest due to the complications and lengthy procedures.

\section{2) The market size}

The local market in Oman is weak. The market size always depends on the GDP. The Sultanate's GDP decreased by $6.4 \%$ in 2020 due to the Corona crisis. Also, in recent years there were fluctuations in the GDP in Oman due to dependence on oil revenues only, which led to an increase in unemployment, low per capita income, and a low production level.

Consequently, consumer demand for products decreased locally, which hinders attracting foreign and domestic investment. Because investors consider that the best companies are the ones that can attract clients to be a sufficient demand to cover costs and achieve profits, on the other hand, GDP growth will increase per capita income. Consequently, the demand for products will grow, which encourages the investor to invest capital in local products because he will be sure of getting profits due to the increasing demand.

\section{3) Lack of investment opportunities}

There is a lack of investment opportunities, and the reason for this is that many local producers and manufacturers have a short-term plan. They want their clients to be limited and local only and make profits quickly without waiting for an extended period. Consequently, the investor cannot find investment opportunities that are compatible with his specialisations and investment criteria.

\section{4) Government regulations}

The government has imposed many new laws which constitute a significant obstacle for investors to invest in Omani products are raising fees for issuing or renewing permits for the non-Omani workforce from 140-300 OMR to 2000-4000OMR. Also, lifting subsidies on electricity and water, imposed a value-added tax on some goods and services, and tax the job security system.

\section{E. The Incentive Provided for Local and Foreign Investors}

As a result of the interview, the ministry offers incentives, privileges, and guarantees to attract and stabilise investors [34]. These incentives are:

\section{1) Tax Exemption}

They exempt local and international investors from taxes for five years from the commencement of production, such as income company tax. Also, they are exempt from customs duties on their imports for five years, such as raw materials, spare parts needed for production, machinery, and equipment that are not available in the local market. Nevertheless, the tax losses during the tax exemption period will be claimed from future profits.

\section{2) Income Tax}

There is no tax on individual income in Oman. Conversely, most countries impose a tax on personal income, whether he foreign local. On the other hand, the tax imposed on companies is $12 \%$ of revenues that exceed 30,000 Omani riyals only.

\section{3) Establishing trade offices}

Allowing foreign companies related to trade and industry to open branches and offices for them in the Sultanate.

\section{4) Capital and profit repatriation}

There are no restrictions on financial transfers, such as debts, capital, interest, profits, and personal savings for investors from Oman to outside.

\section{5) Providing loans to investors}

Foreign and local investors who invest in the industrial sector can obtain financing from the government. Oman Development Bank provides loans to investors, and the most considerable amount that the bank can offer is only one million OMR.

\section{6) The right to own property}

A foreign investor can own shares in an Omani company up to $70 \%$. In some commercial activities, it can reach $100 \%$ according to the regulations of the World Trade Organization (WTO). Also, the foreign investor is entitled to own land for building industrial projects or expanding local productive projects.

\section{CONCLUSION AND RECOMMENDATION}

\section{A. Conclusions}

In conclusion, many challenges face industrial companies from exporting their products to global markets, such as high production costs, insufficient production capacity, high logistics costs, and the lack of technology. Those barriers led to the weakness and shortage in the availability of Omani products in the global markets, and it became unknown. Therefore, this research study discussed a topical issue related to attracting local and international investors to invest in local products and improving the logistics system to support local products to reach global markets and become available and known everywhere.

The study proved that attracting local and foreign capital in local manufacturing is always measured by the availability of an attractive investment environment. Creating a suitable climate for investors focuses on several factors, such as political and economic stability and infrastructure. In addition, it depends on the availability of the investment pillars, incentives, privileges, guarantees provided to investors. Furthermore, overcoming the challenges of attracting investments will significantly improve the business environment for investors.

Therefore, the researcher focused on the challenges that hinder attracting local and international investors to invest in local products, such as complex procedures for obtaining licenses and permit for investors, government regulations, weakness of the local market, and other obstacles. Moreover, attracting local and international investments in local products is insufficient if there is no effective logistical 
system that transfers products from Oman to global markets with high efficiency and productivity. In addition, local producers face many troubles in exporting their products, such as complications in export procedures and customs clearance processes, which cause an obstacle for local industries to reach foreign markets.

\section{B. Recommendations}

- The government should implement the import substitution industrialisation strategy. This strategy works to reduce or prohibit the import of foreign products for which there is an alternative in the local market. For example, the ban on importing Almarai Company's products to replace them Mazoon's products provides dairy products in the local market. Therefore, this strategy will help attract investors to invest in Mazoon products because the investor will be sure that these products will be the only source in the local market, and the demand for them will increase. So, the investor is always looking for products with high demand locally to cover costs and increase profits. Consequently, the investment will support and develop the local product to export to global markets.

- Promotion and marketing of local products, investment opportunities, incentives and privileges provided to investors by:

- Participating in various international conferences, exhibitions, and forums such as Expo Dubai 2020. It is where government officials, investments, decisionmakers, and private sector leaders meet.

- Organising programs and conferences and inviting international and local investors and facilitating their visit to meet local manufacturers, producers, and exporters, and visit local factories and companies to identify local products and markets and for the possibility of investing in it.

- Coordination with the Omani Ministry of Foreign Affairs ambassadors worldwide attracts major investors to invest in the Sultanate and market Omani products globally.

- Oman should join the World logistics passport initiative. WLP is an initiative launched by Dubai early last year to increase commercial opportunities among global markets, and it includes 11 members (Country) [38]. This initiative aims to facilitate trade exchange and build a global logistics network by granting concessions to participating members and international shipping companies, such as saving costs, reducing time, speeding up customs clearance processes, and removing trade barriers. In addition, the logistical passport grants companies and countries access to new markets, commercial diversification in existing products, and facilitation of movement between ports and airports. This program will help Omani exporters reduce logistical costs and provide more opportunities for exporting local products to global markets. On the other hand, this initiative may be an effective strategy to attract more investors from the countries participating in this initiative and marketing local products.

- With the world turned into a world of technology and artificial intelligence. Logistics companies must deepen on artificial intelligence, which calls Fourth Industrial Revolution, in all their operations, such as customs clearance, handling, storage, transportation, and other processes, because technology helps transport goods safely, reducing costs and time. Some of these techniques are shipment tracking systems, the internet of things (IoT) and radio frequency identification (RFID), autonomous trucks and drones, blockchain, warehouse robotics, and other logistics technology. At the same time, investment agencies should use technology and electronic services for coordination and cooperation between them. Also, they must provide an automatic approval service for licenses and approvals for investors to start a business without waiting a long time and reviewing many competent authorities. Moreover, the Ministry of Trade, Industry, and Investment Promotion should facilitate regulations and laws of investment to improve the investment environment.

\section{ACKNOWLEDGEMENT}

First and foremost, I would like to thank God Almighty for all blessings and how he brightens my path to finishing this research study.

I am grateful to my late father for encouraging me to pursue my bachelor's degree. Also, I extend my appreciation and gratitude to my great mother, who has supported me since day one. Finally, I am grateful to have this opportunity to express my genuine feelings to the many people who have contributed their experience and knowledge to the success of this research study.

In specially, I would like to thank my graduation project supervisor, Mrs Hind Huwaishal Al Yaqoopi, for her continuous support, encouragement, and advice, and ideas. Without her constant guidance and comments on each chapter of this research, this study would not have reached the required standard. I also express my sincere thanks and appreciation to Mr Zouhaier Slimi, who played a significant role in the success of this study.

Moreover, I extend my sincere appreciation and thanks to the academic supervisor, Najat Juma Al Maqbali, for her efforts and continuous communication to see the challenges facing me while conducting this research and overcome them. Also, I sincerely thank all the teachers and my colleagues for their support and encouragement in completing this study.

Finally, I thank a lot to all the employees of the Omani investment agencies, particularly the Ministry of Commerce, Industry and Investment Promotion, and the Public Authority for Investment Promotion and Export Development. In addition to logistical services companies, for providing valuable information that contributed to the success of this research study.

\section{REFERENCES}

[1] H. Al Lawati, "The manufacturing sector and the "implementation" stage," 2017. [Online]. Available: https://www.omandaily.om/?p=475203. [Accessed 9 March 2021].

[2] Originoman, "Made in Oman," 2021. [Online]. Available: https://www.originoman.om/about-origin-oman.aspx. [Accessed 9 March 2021]. 
[3] Mazoondairy, "Company Profile," 2021. [Online]. Available: https://www.mazoondairy.om/company-profile/. [Accessed 12 March 2021].

[4] P. De Valk, "Development of the Manufacturing Industries of Oman Preparing for the Future," Ministry of Commerce and Industry, vol. 302, no. 6, pp. 28-30, 2015.

[5] Fanack, "Economy," 2021. [Online]. Available: https://fanack.com/oman/economy/. [Accessed 8 March 2021].

[6] A. Hayes, "What Is an Investment?" 2021. [Online]. Available: https://www.investopedia.com/terms/i/investment.asp. [Accessed 3 March 2021].

[7] W. Kenton, "What Are Logistics?" 2020. [Online]. Available: https://www.investopedia.com/terms/l/logistics.asp. [Accessed 4 March 2021].

[8] Guide, Oman - Country Commercial, "Market Challenges," 2020. [Online]. Available: https://www.trade.gov/country-commercialguides/oman-market-challenges. [Accessed 7 March 2021].

[9] J. Kuepper, "Foreign Direct Investment," 2019. [Online]. Available: https://www.thebalance.com/what-is-foreign-directinvestment-1979197. [Accessed 13 March 2021].

[10] A. Gani, "The Logistics Performance Effect in International Trade," The Asian journal of shipping and logistics, vol. 33, no. 4, pp. 279-288, 2017.

[11] National Center For Statistics And Information, "Manufacturing sector in Oman," National Center For Statistics And Information, Muscat, 2019.

[12] B. Gharleghi, "Determinants of the Foreign Direct Investment in Thailand," Global Review of Accounting and Finance, vol. 7, no. Pp, p. 129 - 139, 2016.

[13] S. N. Balinda, "Factors Attracting Foreign Direct Investments (FDIs) in Rwanda," Saudi Journal of Business and Management Studies, vol. 1, no. 2, pp. 59-67, 2016.

[14] T. P. E. McWilliam, "Made in Oman: Promoting Manufacturing and exporting in the Sultanate Of Oman," Independent Study Project (ISP) Collection, vol. 4, no. 6, pp. 4-13, 2011.

[15] Oxford business group, "Oman focuses on port development," 2020. [Online]. Available: https://oxfordbusinessgroup.com/overview/pivot-point-keyregional-rail-project-hold-sultanate-focuses-port-development. [Accessed 18 March 2021].

[16] W. Tseng and H. Zebregs, "Foreign direct investment in China," International Monetary fund, vol. Pp, no. 133, pp. 2-19, 2002.

[17] C. Simon Fan, "Why China has been successful in attracting foreign direct investment: A transaction cost approach," Journal of Contemporary China, vol. 7, no. 17, pp. 21-32, 2007.

[18] T. Pettinger, "Factors that affect foreign direct investment (FDI)," $2019 . \quad$ [Online]. Available: https://www.economicshelp.org/blog/15736/economics/factorsthat-affect-foreign-direct-investment-fdi/. [Accessed 21 March 2021].

[19] B. Azolibe, "FDI and manufacturing sector growth," International Trade, Politics and Development, vol. 306, no. 11, pp. 3-6, 2020.

[20] T. Pettinger, "Factors that affect foreign direct investment (FDI)," 2019. [Online]. Available: https://www.economicshelp.org/blog/15736/economics/factorsthat-affect-foreign-direct-investment-fdi/. [Accessed 29 March 2021].

[21] P. Wessendorp, D. V. d. Berghe, A. Wigren, S. Young and G. Mele, "Promoting investment and trade," United Nations Conference on Trade and Development, vol. 307, no. 12, pp. 2-10, 2009.

[22] . J. Gross, "Why marketing is SO important," 2016. [Online]. Available: marketing/why-marketing-is-soimportant/\#: :text=Marketing\%20is\%20important\%20because\% 20it,is\%20especially\%20true\%20for\%20SMBs.. [Accessed 29 March 2021].

[23] . U. Stampa, "Integrated logistics: definition, implementation and integration," $2018 . \quad$ [Online]. Available: https://www.smet.it/en/blog-en/integrated-logistics-definitionimplementation-and-integration/. [Accessed 30 March 2021].
[24] J.-P. Rodrigue, "The Benefits of Logistics Investments: Opportunities for Latin America and the Caribbean," InterAmerican development bank, vol. 7, no. 4, pp. 6-45, 2012.

[25] D. Daud, D. A. M. Karim and S. S. Al Shibli, "Integrated Logistics Strategies on the Omani Logistics Firms," Australian Academy of Accounting and Finance Review, vol. 4, no. 1, pp. 37-41, 2018.

[26] Alsi oman, "The challenges in logistics and transportation industry in Oman," 2021. [Online]. Available: https://www.alsioman.com/logistics-transportation-challenges/. [Accessed 16 March 2021].

[27] J. Wisdom, "Mixed Methods: Integrating Quantitative and Qualitative Data Collection and Analysis While Studying PatientCentered Medical Home Models," Agency for Healthcare Research and Quality, vol. 2, no. 7, pp. 3-10, 2013.

[28] R. Streefkerk, "Qualitative vs quantitative research," 2019. [Online].

Available: https://www.scribbr.com/methodology/qualitative-quantitativeresearch/\#: :text=Quantitative\%20research\%20deals\%20with\%2 0numbers $\% 20$ and $\% 20$ statistics $\% 2 \mathrm{C} \% 20$ while $\% 20$ qualitative $\% 2$ 0research,ideas\%20and\%20experiences\%20in\%20depth.. [Accessed 8 April 2021].

[29] P. Bhandari, "An introduction to quantitative research," 2020. [Online]. Available: https://www.scribbr.com/methodology/quantitative-research/. [Accessed 9 April 2021].

[30] Humans of data, "6 Sampling Techniques: How to Choose a Representative Subset of the Population," 2017. [Online]. Available: https://humansofdata.atlan.com/2017/07/6-samplingtechniques-choose-representative-subset/. [Accessed 14 April 2021].

[31] J. Crosley, "What (Exactly) Is Thematic Analysis?" 2021. [Online]. Available: https://gradcoach.com/what-is-thematicanalysis/. [Accessed 21 May 2021].

[32] N. Dhand, "Descriptive Analysis: Take it easy!" 2015. [Online]. Available: http://www.statulator.com/blog/descriptive-analysistake-it-easy/. [Accessed 22 May 2021].

[33] K. Al-Badwawi, Interviewee, The reasons for complex and lengthy procedures. [Interview]. 3 May 2021.

[34] A. Al-Jabri, Interviewee, Investment incentives provided to investors. [Interview]. 2 May 2021.

[35] R. Wahaibi, Interviewee, Marketing and promotion of investment opportunities and local products. [Interview]. 10 April 2021.

[36] Tellerreport, "The high quality of local products enabled them to export to international markets," 2019. [Online]. Available: https://www.tellerreport.com/business/2019-12-15---companies-the-high-quality-of-local-products-enabled-them-to-export-tointernational-markets-.H1x54kVVCr.html. [Accessed 13 May 2021].

[37] A. Al-Makhmari, Interviewee, The performance of logistics sector in Oman. [Interview]. 28 April 2021.

[38] Z. Mansoor, "Dubai's World Logistics Passport initiative expands network," $2021 . \quad$ [Online]. Available: https://gulfbusiness.com/dubais-world-logistics-passportinitiative-expands-network/. [Accessed 28 May 2021].

[39] B. Morgan, "50 Statistics Showing The Lasting Impact Of COVID-19 On Consumers," 19 October 2020.

[40] OECD, "E-commerce in the time of COVID-19," OECD Policy Responses to Coronavirus (COVID-19), 07 October 2020.

[41] M. Khosrow-Pour, Encyclopedia of e-commerce, e-government, and mobile commerce, illustrated edition ed., Idea Group Reference, 2006.

[42] A. Raijas and V. K. Tuunainen, "Critical factors in electronic grocery shopping," The International Review of Retail, Distribution and Consumer Research, vol. 11, no. 3, pp. 255-265, 2011.

[43] L.-J. Ho, " The influences of social commerce characteristics on satisfaction, reliability and repurchase intention.," pp. 16-25, 2013.

[44] Zhang, Y. Fang and H. Chen, "Repurchase intention in B2C ecommerce - A relationship quality perspective," pp. 192-200, 2011.

[45] Euromonitor, "COVID-19 to Accelerate Online Grocery Shopping Beyond 2021," 2020. [Online]. Available: 
https://blog.euromonitor.com/covid-19-to-accelerate-onlinegrocery-shopping-beyond-2021/. [Accessed 2602 2021].

[46] Z. Anesbury, M. Nenycz, J. Dawes and R. Kennedy, "How do shoppers behave online? An observational study of online grocery shopping," Consumer Behaviour, vol. 15, no. 3, pp. 261-270, 2015.

[47] OECD, "Food Supply Chains and COVID-19: Impacts and Policy Lessons," $2020 . \quad$ [Online]. Available: http://www.oecd.org/coronavirus/policy-responses/food-supplychains-and-covid-19-impacts-and-policy-lessons-71b57aea/. [Accessed 24 February 2021].

[48] OECD, "Connecting Businesses and Consumers During COVID19: Trade in Parcels," OECD, Globally, 2020.

[49] OECD, "COVID-19 and the retail sector: impact and policy responses," $2020 . \quad$ [Online]. Available: http://www.oecd.org/coronavirus/policy-responses/covid-19-andthe-retail-sector-impact-and-policy-responses-371d7599/.. [Accessed 24 February 2021].

[50] N. N. Long and B. H. Khoi, "An Empirical Study about the Intention to Hoard Food during COVID-19 Pandemic," vol. 16, no. 7, 2020.

[51] A. Bjørgen, K. Y. Bjerkan and O. A. Hjelkrem, "E-groceries: Sustainable last-mile distribution in city planning," Research in Transportation Economics, p. 9, 2019.

[52] M. Henriksson, J. Karlsson, S. Rogerson and J. Berg, "The impact of increased e-commerce for passenger and freight transport in an increasing e-commerce society," Buying food online?, p. 71, 2018.

[53] A. Banerjee and F. Siemens, "Logistics of E-Groceries," Innovations and Strategies for Logistics and Supply Chains, vol. 20, pp. 91-116, 2015.

[54] P. Schnedlitz, E. Lienbacher, B. Waldegg-Lindl and M. WaldeggLindl, "Last Mile: Die letzten - und teuersten - Meter zum Kunden im B2C ECommerce," pp. 249-273, 2013.

[55] N. A. Agatz, A. Campbell and M. Savelsbergh, "Time Slot Management in Attended Home Delivery," Transportation Science, vol. 45, no. 3, p. 435-449, 2011.

[56] J. L. Anderson, L. D. Jolly and A. E. Fairhurst, "Customer relationship management in retailing," A content analysis of retail trade journals, vol. 14, no. 6, p. 394-399, 2007.

[57] D. Grewal, A. L. Roggeveen and J. Nordfalt, "The Future of Retailing," vol. 93, no. 1, pp. 1-6, 2017.

[58] I. Cil, D. Ay and Y. S. Turkan, "Data-driven decision support to supermarket layout," pp. 465-470, 2009.

[59] K. v. Ittersum, B. Wansink and J. M. Pennings, "Smart Shopping Carts," How Real-Time Feedback Influences Spending, vol. 77, no. 6, p. 21-36, 2013.

[60] S. Yang, Y. Song and S. Tong, "Sustainable Retailing in the Fashion Industry," A Systematic Literature Review, vol. 9, no. 7, p. 1266, 2017.

[61] Shoppu, "Malaysian online shopping insights," 2016. [Online]. Available: https://www.ecommercemilo.com/2016/03/malaysianonline-shopping-insights-2016. [Accessed 11 November 2020].

[62] W. Wang, Y. Liu and Y. Wei, "Research on management strategies of reverse logistics in e-commerce environments," Journal of System and Management Sciences, vol. 3, no. 2, pp. 45$50,2013$.
[63] S. Nasir and B. Kurtuluş, "Technology Is Transforming Shopping Behavior," In-Store Mobile Technology Usage, pp. 1508-1529, 2017.

[64] N. Ramli, "THE ART OF CUSTOMER SERVICE TECHNIQUES," $2015 . \quad$ [Online]. Available: https://prezi.com/g5mqeth8ldih/the-art-of-customer-servicetechniques/. [Accessed 05 December 2020].

[65] S. K. Panigrahi, F. W. Kar, T. A. Fen, L. K. Hoe and M. Wong, "A Strategic Initiative for Successful Reverse Logistics Management in Retail Industry," vol. 19, no. 1, pp. 1-25, 2018.

[66] B. K. Karel, M. T. Frohlich, G. Hult and Tomas M, Extending the supply chain: how cutting-edge companies bridge the critical last mile into customers' homes, 1st ed., New York: American Management Association, 2005.

[67] R. Frankel, T. J. Goldsby and J. M. Whipple, "Grocery industry collaboration in the wake of ECR," International Journal of Logistics Management, vol. 13, no. 1, p. 57-72, 2002.

[68] K. Verweire and L. V. D. Berghe, Integrated Performance Management, London: SAGE Publications, 2004.

[69] T. Esper, T. D. Jensen F. Turnipseed and S. Burton, "The last mile: an examination of effects of online retail delivery strategies on consumers," Journal of Business logistics vol. 24, no. 2, pp. 177 203, 2003.

[70] J. Creswell, Research design (Qualitative, Quantitative, and Mixed Methods Approaches), Los Angeles: SAGE 2014.

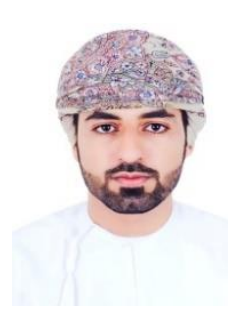

Abdulaziz Khalid Mohammed Al-Makhmari: A graduate in logistics and transportation management from the International Maritime College Oman.

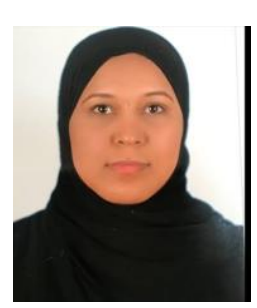

Mrs Al Yaqoobi is an assistant lecturer at the International Maritime College Oman in Logistics Management Department. Holder of a bachelor's degree in port, Shipping and Transport Management (Logistics Management) from International Maritime College Oman. Current Master student in International Operations and Supply Chain Management in Glasgow Caledonian University/Scotland.

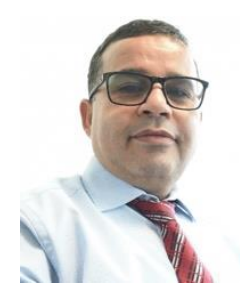

Mr Slimi is an English language lecturer at the international Maritime college Oman at the Foundation Department. Holder of BA in English Language and Literature from t faculty of Arts and Humanities Sousse/Tunisia, TESOL from ITTT, Masters' Degree in the Arts of Learning and Teaching from Roehampton University/UK and current $\mathrm{PhD}$ student at the Department of Psychology and Education Deusto University Spain. Mr Slimi is an editor at the European Journal of Education Sciences (EJES). 